\title{
Influence of Performance Appraisal on Performance of Universities in Machakos and Kitui Counties, Kenya
}

\author{
Annah Mumbua Mbiti, Robert Arasa, and Jacinta Kinyili
}

\begin{abstract}
Through performance appraisal an organization undertakes to measure the set goals against employee actual performance with respect to the period in question. It is also used to identify an employee's weaknesses and strengths and provide for appropriate adjustments. This study examined the influence of performance appraisal on organizational performance in Universities within Machakos and Kitui Counties in Kenya. A descriptive research design was adopted and both qualitative and quantitative data was collected. The study targeted staff working in the selected departments of administration, human resource, finance and audit, procurement, deans of schools and directorate of quality assurance. Stratified sampling procedure was used from which 45 out 263 respondents were targeted. Purposive sampling was then employed because the study was interested in heads of departments. The main data collection tool was the questionnaire with both open and closed ended questions. In addition interviews were conducted with some heads of departments to ascertain some of the information in the questionnaires. Both descriptive and inferential statistics analysis was used to aid addressing the objective of the study. The study findings revealed that there was effective performance appraisal procedures and methods in place that were used by the management within the universities studied in assessing the employees performance on the set targets of the universities. The correlation coefficients and regression analysis result indicates that performance appraisal has a positive and statistically significant influence on human resource on performance of universities; $\mathrm{P}<\mathbf{0 . 0 5}(\mathrm{P}=\mathbf{0 . 0 0})$ with explanatory power of $78.7 \%$. The study recommends that clear job descriptions for each staff should be well spelt out as this in the basis for appraising the employees. This will mitigate against possible situations of confusion and dissatisfaction of employees which arises when they do not understand what is expected of them leading to failure in meeting their set targets. University managements should also ensure that there is participatory target setting, aligning the same to the bigger goals of the university and adequate staff support in the execution of set targets as this has implications on the overall performance of the institution.
\end{abstract}

Index Terms-Organizational Performance, Performance Appraisal, Performance Appraisal Methods, Universities

\section{INTRODUCTION}

\section{Human Resource Management Practices and Performance of higher learning institutions}

[7] holds that institutions of higher learning can use several HRM practices to develop employee skills and motivate them to increase their commitment to achieve the set targets. Studies show that proper use of some human resource management practices assist employees to be dedicated of their work hence good performance of the universities [6] Most of these institutions fail to attain their set goals due to poor human resource management practices that affect commitment of employees' and demotivate the staff which in turn affects the overall performance of the universities [7], [5] A study [19] on state of university education in Kenya between 2012 and 2015 found out that universities growth had increased tremendously standing at 539,749 with public universities registering $461,820(86 \%)$ and private universities registering 77,929 (14\%). However, the study also established that the public universities were seriously underfunded by the government and were spending more than their income. Unfortunately, due to increased competition and government policies, most public and private institutions especially universities in Kenya have mainly channeled resources to infrastructural development neglecting essentials of human resource management [21]. Studies have shown that human resource management practices such as recruitment and selection, training and development, performance appraisals, performance-based compensation, and other practices like extensive information sharing, job security, welfare benefits and grievance systems are neglected [26]. [25] claim that very little has been done to establish the influence of HRM practices on performance of universities in Kenya. Performance appraisal is one of these practices that is expected when carried out well to positively contribute to both the staff and institutional performance.

Performance appraisal is a process in which an employee performance is evaluated considering quality, quantity, cost and time. [15] stated that performance appraisal advances performance of employees by increasing productivity that also increases organizational performance. Performance appraisal aims at giving feedback on employees' performance, identifying employee training needs, documenting procedures used to allocate organizational rewards, making personnel decisions, providing opportunity for organizational diagnosis and development, and facilitating communication between employee and administration [16]. Performance management involves an on-going dialogue between a supervisor and an employee that links expectations, on-going feedback, coaching, performance evaluation, development planning, and a follow up (Make staff Review Count, 2009). Using objectives defined by senior management, supervisors define expectations for every position in their department. These expectations in combination with the organization's performance measurement standards are communicated to the employees and are typically reviewed at least once a year with all employees. Expectations for each position can include purpose of the position, key responsibilities, tasks and 
duties, expectations for conduct, and performance standards, as well as specific measures such as quality, quantity, timeliness, initiative, and teamwork for each key responsibility (Make staff Review Count, 2009). The development and improvement of an employee's behavioral competencies demonstrates, in measurable terms, how the employee is living up to the expectations [2]. The commonly used methods for conducting performance appraisal process are: management by objectives (MBO), 360 degree appraisal, behavioral observation scale and behaviorally anchored rating scale [2]. Organizational success is affected by the extent to which employees are determined to work that extra mile [1]. [29] discovered that PA is related to achieving good results. However, [4] argue that appraisal practices that are ineffective affects employee morale, productivity and discourage them from working towards organizational goals.

\section{A. Statement of the Problem}

One of the key issues is that the HRM Practices and the performance goals of these institutions of higher learning are often disconnected from performance management, which is a function of strategic HR in managing employee performance in universities [5]. Performance management through the staff performance appraisal programs is seen as one of the critical HRM practices that can trigger improved staff output and eventual organizational performance.

According to [29] web metrics in Kenya that assessed universities on three aspects: being chartered, licensed and accredited by the regulatory body, offering 4 year undergraduate or postgraduate degrees and practicing one on one student-lecture courses, Daystar was ranked position 14 followed by South Eastern Kenya University (SEKU) position 19, Machakos university (MksU) position 39 and Scott Christian the last at position 45. Studies on HRM practices over the last decade have gained momentum and have become an issue of concern to the public on how organizations bring on board and maintain their staff in order to achieve organizational goals. A survey done in two of the universities under investigation showed that there has been a remarkable improvement on student enrolment and graduation lists expanding each year, hosting of research conferences in collaboration with other organizations, from their repositories it is seen that there are considerable publications from their respective staff/post graduate students and also attraction of both internal and external research projects grants. Thus this study sought to examine the influence of performance appraisal on the performance of these institutions.

\section{LITERATURE REVIEW}

\section{A. Theoretical review}

This study was anchored on agency theory and goal setting theory. The agency theory developed by Ross and Mitnick in 1973 states that a firm consists of a series of contracts formed between the owners of economic resources who are the shareholders and managers who are the agents and are delegated with the responsibility of controlling those resources [9]. The theory posits that agents have more information than principals and that this information asymmetry adversely affects the principals' ability to monitor whether or not their interests are being properly served by agents. The theory suggests that, in order to harmonize the interests of the agent and the principal, a comprehensive contract is written to address the interest of both the agent and the principal. The agent-principal relationship is strengthened more by the principal employing an expert and systems (auditors and control systems) to monitor the agent [12]. Further the theory recognizes that any incomplete information about the relationship, interests or work performance of the agent described could be adverse and a moral hazard. For this study, there is expected to be that understanding and compelling direction by the University Councils and management (through the CEOs or Vice Chancellors) to monitor staff output and university performance in general.

Goal Setting Theory developed by Latham and Locke in 1968 emphasizes on four pillars that bind goals to performance results [13]; first, goals direct attention to priorities, secondly goals kindle efforts, thirdly, goals challenge people in order to increase their success and lastly goals are challenging such that they force people to employ all their skills [13]. The theory holds that people feel motivated when a token is assured after accomplishing a given task or attaining a prescribed behavior. The goal setting theory therefore suggests that when a task is accomplished and it is rewarded, it turns to be a motivator of that performance of the task [9] Setting goals helps a person set targets which will determine their behavior. When people feel that the current goals cannot be achieved by the behavior they are holding currently, they will either change the behavior or modify their goals [13]. The theory emphasized on setting goals and agreeing on what measures performance can be managed. The goals should be specific and measurable. The theory states that there must be an agreement on objectives, feedback and strategies used to achieve the goals [12]. Feedback enables a person to gauge the actual performance with the set targets and take corrective action where necessary. Clear goals assist employees in discovering what is to be achieved and focusing on that direction [14]. The goal setting theory adopts that there is a positive relationship between measurable goals and performance. If clear lines are set, people are willing to put more efforts and achieve the objectives [13]. This theory is relevant to the study because during appraisal of staff, there must be set goals that are measured against their actual performance.

\section{B. Empirical Review}

Performance Appraisal (PA) is a formal process of reviewing and evaluating employee performance and providing a corrective action if targets are not met or giving a credit of work well done (Make staff Review Count, 2009). The aims of PA are; organizational goal alignment, manager-employee communication, employee development, effective personnel administration [28], [17], [10]. Organizations goal alignment is the ultimate objective of a performance management process where individual performance is aligned with organizational performance [28]. [8] argues that the goal of alignment process is to create a result-oriented culture which is a significant benefit of the performance appraisal exercise. According to [30] argue that manager-employee communication is the rapport between employees and management about the feedback on organizational activities, events and performance towards organizational goals and objectives. 
[3] state that performance appraisal is more limited approach which involves managers making top-down assessment and rating the performance of their subordinates at an annual performance appraisal meeting. [3] continues to say PA system helps an employee discover his strengths and weaknesses and help him in decision making about his career choices.

[1] describe the role of PA as a tool for looking forward on what need to be done by people in an organization in order to achieve the purpose of the job to meet new challenges.

[12] reported that performance management is a strategy employed by institutions to help them work towards achieving their goals by properly using human resources through identifying their competences towards the organization. [20] in his study at Machakos level V hospital found out that employees expected more than what their jobs could give in this era of technological changes. Many organizations in Kenya, concur that appraisal help them to establish the need for training of employees. It is also used as a benchmark for increasing employee salaries [18] However, Muchiri noted that appraisal process is affected by lack of set guidelines and appraisers who are not trained. A study by [31] showed that PA was not used in enhancing employee performance. [31] noted that employees rated below average were demoralized and believed that their bosses were in bad faith. Paul et al (2015) in their study on modeling the relationship between performance appraisal and organizational productivity in Nigerian public sector adopted descriptive survey design and found out that if employees got regular feedbacks about their performance on the jobs, this could ensure competitive positioning for the organization.

\section{THE CONCEPTUAL FRAMEWORK}

Independent variable Dependent variable

\begin{tabular}{|c|c|}
\hline $\begin{array}{l}\text { Performance } \\
\text { Appraisal } \\
\text { - Appraisal } \\
\text { system } \\
\text {-Target setting } \\
\text {-Achievement } \\
\text { of targets } \\
\text {-Feedback }\end{array}$ & $\begin{array}{cl}\text { Organization } \\
\text { Performance } \\
\text { - } & \text { Student } \\
& \text { Enrolment } \\
\text { - } & \text { Quality } \\
& \text { Graduates } \\
\text { - } & \text { Publications } \\
& \text { and citations } \\
\text { - } & \text { Research } \\
& \text { grants }\end{array}$ \\
\hline
\end{tabular}

\section{RESEARCH METHODOLOGY}

\section{A. Research Design and Target Population}

This study adopted a descriptive research design. According to [11] it is a systematic technique used to observe and describe the comportment of a matter without any influence. The research design involved collecting data in order to answer questions concerning the current status of the subject of the study [11].

The study targeted 263 staff in the universities under investigation as shown through table 1 . The study used $17 \%$ of the total population which gave a sample size of 45 respondents distributed across seven departments in each university namely: administration, deans of schools, human resource, procurement, finance and audit and directorate of quality assurance, each department being treated as a stratum. The total number sampled in each department or stratum was arrived at by getting the number of total population in each department and dividing by the overall total population in all the universities then multiplying by the total number of the sample size.

$$
\begin{aligned}
& \frac{\text { No. of population in the department }}{\text { Total overall population }} \times \frac{\text { sample }}{\text { size informed }} \\
& \text { by } 17 \% \text { of the } \\
& \text { total population }
\end{aligned}
$$

\section{$=\underline{\mathrm{n}} \times 45=$ no. sampled per department 263}

\begin{tabular}{|c|c|c|c|c|c|}
\hline Section & MksU & SEKU & Scott & $\begin{array}{l}\text { Day } \\
\text { Star }\end{array}$ & Total \\
\hline $\begin{array}{l}\text { Human Resource } \\
\text { Directorate of } \\
\text { Quality Assurance } \\
\text { Deans of schools } \\
\text { including post } \\
\text { graduate school } \\
\text { Administration } \\
\text { Finance\& Audit } \\
\text { Procurement } \\
\text { TOTAL }\end{array}$ & $\begin{array}{l}10 \\
3 \\
10 \\
\\
23 \\
19 \\
17 \\
82\end{array}$ & $\begin{array}{l}20 \\
5 \\
9 \\
\\
34 \\
22 \\
20 \\
\mathbf{1 1 0}\end{array}$ & $\begin{array}{l}3 \\
1 \\
3 \\
8 \\
3 \\
5 \\
\mathbf{2 3}\end{array}$ & $\begin{array}{l}10 \\
2 \\
5 \\
\\
18 \\
6 \\
7 \\
48\end{array}$ & $\begin{array}{l}43 \\
11 \\
27 \\
\\
83 \\
50 \\
49 \\
263\end{array}$ \\
\hline
\end{tabular}

Purposive sampling was employed to pick heads of departments.

\section{TABLE 1: TARGET POPULATION}

Source: HR departments (2018) in the universities

\section{B. Validity of the Instruments}

[11] suggested that the validity of the instrument is about asking the right questions framed from the least ambiguous way and based on study objectives. The validation of the instruments for this study was done by pre-testing the questionnaire, discussing with various relevant stakeholders. Based on the feedback from the pilot test, the questionnaire was modified and a final one developed

\section{Reliability of the Instruments}

Cronbach alpha, was used to test for reliability of the instrument. The higher the score, the more reliable it is. Bryman and Bell (2013) indicated that a Cronbach's alpha of 0.7 is an acceptable reliability. In this study, a Cronbach's Apha of 0.7 was considered acceptable reliability. 


\section{Data collection}

It involved collection of data through questionnaires and an interview schedule. Data was collected through a questionnaire and an interview schedule. This study utilized a questionnaire and interview schedule which was used to collect quantitative and qualitative data respectively.

\section{1) Data analysis}

The study used descriptive statistics to analyze data. This was to aid in establishing the status of affairs with respect to the variables of interest and also establish relationship between the variables investigated. Data was then presented in form of graphs, pie charts and tables for descriptive analysis. Correlation analysis and simple linear regression analysis were performed to determine the direction and level of relationship between the independent variable and the dependent variable. The regression model used is shown below.

$\mathrm{Y}=\alpha+\beta_{1} \mathrm{X}_{1}$

Where: $\mathrm{Y}=$ Dependent variable

$\alpha=$ constant

$\mathrm{X}_{1}=$ Independent variable

$\beta_{1}=$ regression coefficients for respective variables

$\varepsilon$ is the error term

Hence; $\mathrm{Y}=$ Organizational performance

$\mathrm{X}_{1}=$ Performance Appraisal

\section{RESEARCH FINDINGS AND DISCUSSION}

\section{A. Introduction}

This chapter presents the findings and discussions of the analysis results based on the information gathered from the respondents. The findings are presented in percentages and frequency distribution, mean and standard deviation as well as regression analysis. A total of 45 questionnaires distributed to four universities, namely Machakos University, South Eastern Kenya University, Daystar University and Scotts University. Out of the 45 distributed questionnaires, 42 were filled and returned. This translated to a response rate of 93.3\%. From the findings, the overall Cronbach's Alpha coefficient for Performance Appraisal statements/subactivities was 0.764 which acceptable.

\section{B. Demographic information}

Of those who responded, $40.5 \%$ had attained Degree level, $31 \%$ had attained Doctorate while $28.5 \%$ had attained masters/post graduate diploma. This implied that the respondents were of good education level and grasped well the issues of interest in this study.

On working duration, majority of the respondents (43.80\%) had a work experience of over 16 years, $35.54 \%$ had worked for a period of between 11-15 years, $19.01 \%$ had worked for a period of between $6-10$ years and $9.92 \%$. had worked for less than 5 years. The study showed that majority of the respondents had been working for a long time hence were familiar with human resource management practices and institution performance trends over

\section{Descriptive analysis}

Descriptive statistics was used to summarize the data collected. Tools used were measures of central tendency and measures of variability or dispersion.

\section{1) Existence of performance appraisal practices}

The study aimed at determining if Performance Appraisal and evaluation practices for the employees were in existence in universities in Machakos and Kitui Counties. Majority of the respondents $(88.10 \%)$ indicated that the specified performance appraisal practices were effectively carried out in the university they were working for while only $11.90 \%$ indicated otherwise. This finding implied that performance appraisal was used to determine if the employees were meeting the set departmental goals and objectives and those of the university as a whole.

\section{2) Performance Appraisal in a Year}

Data was analyzed to determine the different Performance Appraisal interval in a year used by the universities in Machakos and Kitui Counties. Figure 1 below indicates that majority $(52.4 \%)$ of the respondents indicated that the department they were working for in different universities were appraised after every six months which would enable employees strive hard so as to achieve department goals before the end of financial year. $28.6 \%$ of the respondents indicated that they were appraised on quarterly basis based on the performance contract targets signed while $19.0 \%$ of the respondents were evaluated only once a year which was not adequate enough for the employees to make noticeable changes. From the finding it implied that quarterly basis and six months appraisal interval was the best for the employees to make improvements on their performance target.

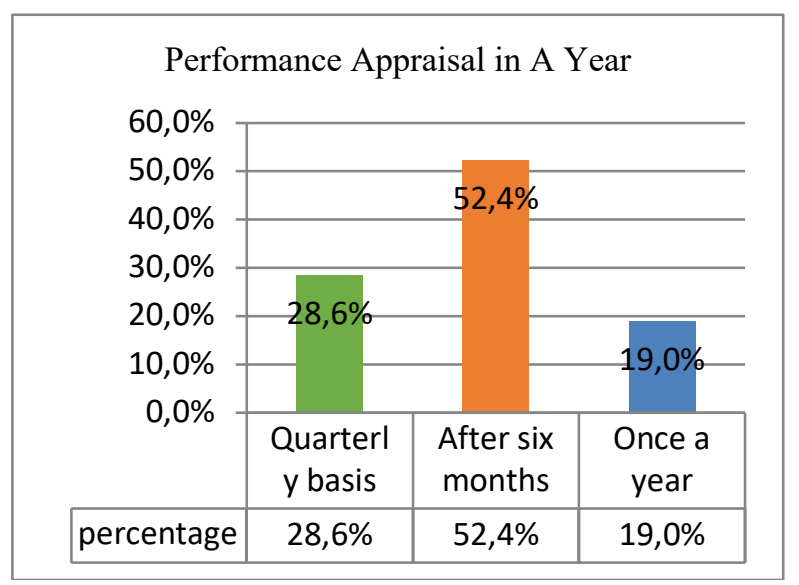

\section{3) Staff Appraisal Methods}

Respondents were required to indicate the Staff Appraisal methods used by their respective universities. $19 \%$ of the respondents indicated that the institution they were working for uses rating scale method, $12 \%$ indicated that the institution were using report writing in form of confidential reports, $5 \%$ of the respondents indicated that ranking method was used, $55 \%$ indicated that $360^{\circ}$ method was used at their university while only $9 \%$ of the respondents showed that paired comparison was used in their university. This finding is shown in figure 2. From the findings it was noted that the 
staff appraisal methods used were competitive and fair to all members of the universities across all the departments.

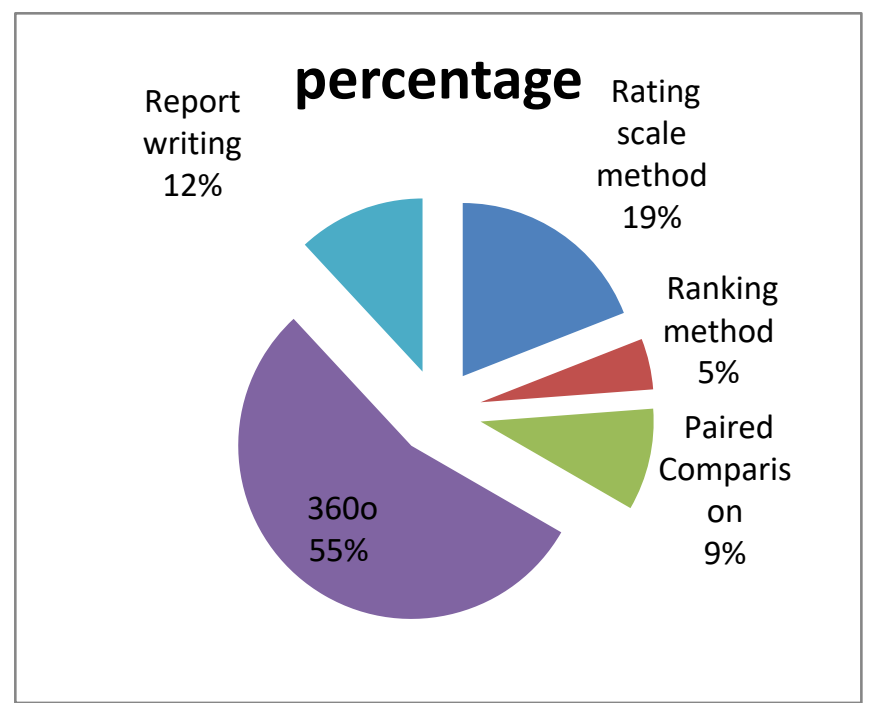

4) Performance Appraisal and University
Performance

The respondents were requested to indicate their level of agreement (on a likert scale of 1-5 where strongly disagree $=1$, disagree $=2$, not sure $=3$, agree $=4$, and strongly agree $=5$ ) with various statements that relate to the influence of Performance Appraisal on organizational/university performance. From the findings $59.52 \%$ of the respondents agreed the university communicates in a timely manner and effectively to the employees, with $30.95 \%$ of the respondents strongly agreeing while $2.38 \%$ of the respondents were neutral while only $4.76 \%$ disagreed to the statement. The study revealed that Staff contributions/opinions towards their appraisals are noted and incorporated in establishing corrective actions with $66.67 \%$ of the respondents agreeing and $16.67 \%$ of the respondents strongly agreeing with only $2.38 \%$ of the respondents disagreeing to the statement.

The study findings indicated that the appraisal was used to realign business objectives with changing market conditions; making targets relevant and accurate. $61.90 \%$ of the respondents agreed, $21.43 \%$ of the respondents strongly agreed and only $4.76 \%$ disagreed to the statement. From the findings $33.33 \%$ of the respondents strongly agreed that goals and objectives of the organization are clearly understood by the employees with $54.76 \%$ of the respondents agreeing and only $2.38 \%$ of the respondents being neutral. From the findings this implied that a systematic and collaborative approach was used to appraise the performance of the employee. These results are presented in table 2 below. These findings concurred with those of Kondrasuk (2011) which noted that well-constructed Performance Appraisal could be valuable tools for communication with employees as pertaining to how their job performance stands with organizational expectations.
TABLE 2: PERFORMANCE APPRAISAL

\begin{tabular}{|c|c|c|c|c|c|}
\hline Statement & 1 & 2 & 3 & 4 & 5 \\
\hline The university & 2.38 & 4.76 & 2.38 & 59.52 & 30.95 \\
\hline $\begin{array}{l}\text { communicates in a } \\
\text { timely manner and } \\
\text { effectively to the } \\
\text { employees }\end{array}$ & $\%$ & $\%$ & $\%$ & $\%$ & $\%$ \\
\hline Staff & 2.38 & 7.14 & 7.14 & 66.67 & 16.67 \\
\hline $\begin{array}{l}\text { contributions/opinion } \\
\mathrm{s} \text { towards their } \\
\text { appraisals are noted } \\
\text { and incorporated in } \\
\text { establishing } \\
\text { corrective actions }\end{array}$ & $\%$ & $\%$ & $\%$ & $\%$ & $\%$ \\
\hline The appraisal is used & 4.76 & 4.76 & 7.14 & 61.90 & 21.43 \\
\hline $\begin{array}{l}\text { to realign business } \\
\text { objectives with } \\
\text { changing market } \\
\text { conditions; making } \\
\text { targets relevant and } \\
\text { accurate. }\end{array}$ & $\%$ & $\%$ & $\%$ & $\%$ & $\%$ \\
\hline Goals and objectives & 7.14 & 2.38 & 2.38 & 54.76 & 33.33 \\
\hline $\begin{array}{l}\text { of the organization } \\
\text { are clearly } \\
\text { understood by the } \\
\text { employees }\end{array}$ & $\%$ & $\%$ & $\%$ & $\%$ & $\%$ \\
\hline
\end{tabular}

\section{5) Performance of Universities}

Respondents were asked to indicate the level of agreement with statements on the various performance dimensions (indicators) on a likert scale of 1-5 (where strongly disagree $=1$, disagree $=2$, not sure $=3$, agree $=4$, and strongly agree $=5$ ). The main and relevant performance indicators considered were; student enrolment rate, university ranking, student completion duration, research and publications, attraction of grants, From the findings, the respondents to moderate extent agreed application of the human resource strategies enabled the university high enrolment rates with $21.43 \%$ of the respondents strongly agreeing, $64.29 \%$ of the respondents agreeing and $4.76 \%$ of the respondents disagreed. Further the study provided that respondents to a great extent concurred that students graduated within the stipulated time with $30.95 \%$ of the respondents strongly agreeing, $52.38 \%$ of the respondents agreeing and $7.14 \%$ of the respondents disagreeing. These finding is presented through table 3 below.

On whether universities have been ranked highly in the recent web ranking in the region and in the continent due to application of key strategies in managing the work force, $33.33 \%$ of the respondents strongly agreed, $54.76 \%$ of the respondents agreed with only $2.38 \%$ of the respondents disagreeing. From the findings it was observed that human resource management enable the universities to be competitive in the region as well providing quality graduate in every assessment. 
TABLE 3: PERFORMANCE OF THE UNIVERSITIES

\begin{tabular}{|c|c|c|c|c|c|}
\hline Statement & 1 & 2 & 3 & 4 & 5 \\
\hline $\begin{array}{l}\text { The university has a } \\
\text { high enrolment rates }\end{array}$ & $2.38 \%$ & $4.76 \%$ & $7.14 \%$ & $64.29 \%$ & $21.43 \%$ \\
\hline $\begin{array}{l}\text { Graduates from the } \\
\text { university are well } \\
\text { equipped to } \\
\text { undertake research } \\
\text { projects }\end{array}$ & $7.14 \%$ & $2.38 \%$ & $2.38 \%$ & $61.90 \%$ & $26.19 \%$ \\
\hline $\begin{array}{l}\text { Students from the } \\
\text { university graduate } \\
\text { within the stipulated } \\
\text { time }\end{array}$ & $2.38 \%$ & $7.14 \%$ & $7.14 \%$ & $52.38 \%$ & $30.95 \%$ \\
\hline $\begin{array}{l}\text { The university has } \\
\text { invested fairly in } \\
\text { research }\end{array}$ & $4.76 \%$ & $2.38 \%$ & $7.14 \%$ & $54.76 \%$ & $30.95 \%$ \\
\hline $\begin{array}{l}\text { There is tremendous } \\
\text { rise of publications } \\
\text { and citations from } \\
\text { the staff }\end{array}$ & $4.76 \%$ & $2.38 \%$ & $4.76 \%$ & $57.14 \%$ & $30.95 \%$ \\
\hline $\begin{array}{l}\text { Staff have attracted } \\
\text { considerable } \\
\text { research grants }\end{array}$ & $2.38 \%$ & $2.38 \%$ & $2.38 \%$ & $52.38 \%$ & $40.48 \%$ \\
\hline $\begin{array}{l}\text { The university is } \\
\text { ranked highly in the } \\
\text { recent web ranking } \\
\text { in the region and in } \\
\text { the continent }\end{array}$ & $2.38 \%$ & $2.38 \%$ & $7.14 \%$ & $54.76 \%$ & $33.33 \%$ \\
\hline
\end{tabular}

D. Inferential Analysis

1) Correlation analysis results

The study undertook correlation analysis to examine the relationship between performance appraisal and university performance. The correlation factor ranged from $-1 \leq 0 \geq 1$ and the acceptance confidence level was $95 \%$ or significance level of 0.05 . The study conducted a Pearson Moment Correlation analysis, which is represented by $\boldsymbol{r}$ for the study variables Performance Appraisal and Organization performance. Table 4 presents the correlation analysis results. The results reveal that Performance Appraisal has a strong positive influence on organizational performance as attributed by the correlation coefficient of 0.851 and a p-value of 0.00. This result implies that Performance Appraisal impacts on the performance of the universities in Machakos and Kitui Counties.

\section{TABLE 4: CORRELATIONS ANALYSIS RESULTS}

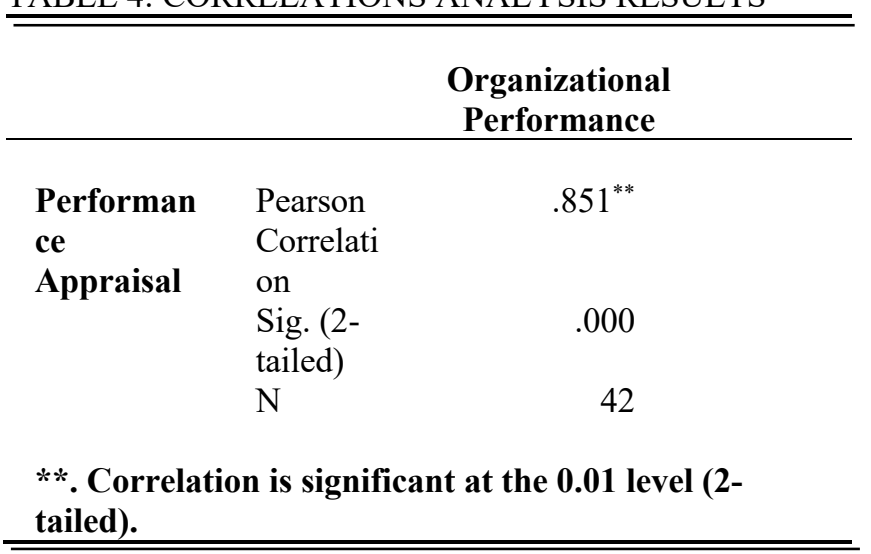

\section{2) Regression Analysis}

The study conducted regression analysis to determine the influence of staff appraisal on organizational performance in universities in Machakos and Kitui Counties. The study results are shown in the subsequent sections. Table 5 shows that the coefficient of determination $\mathrm{R}^{2}$ is 0.787 This means that the influence of the predictor variable (Performance Appraisal) explains $78.7 \%$ of the organizational performance of universities in Machakos and Kitui Counties.

\begin{tabular}{lrrrr}
\multicolumn{4}{l}{ TABLE 5: MODEL SUMMARY } \\
\hline Model & $\mathbf{R}$ & $\begin{array}{c}\mathbf{R} \\
\text { Square }\end{array}$ & $\begin{array}{c}\text { Adjusted } \\
\mathbf{R} \\
\text { Square }\end{array}$ & $\begin{array}{c}\text { Std. } \\
\text { Error of } \\
\text { the } \\
\text { Estimate }\end{array}$ \\
\hline $\mathbf{1}$ & $.887^{\mathrm{a}}$ & .787 & .763 & .399 \\
\hline \hline
\end{tabular}

a. Dependent Variable: Organization Performance b. Predictor: Performance Appraisal

The study findings demonstrated that universities that have embraced performance appraisal concept in managing their human resource had significant improvement on the performance of the organization simple regression results revealed that Performance Appraisal has significant influence on organizational performance of universities in Machakos and Kitui by $\beta 3=0.591, p=0.002<0.05, t=2.049$ the implication is that a unit increase in Performance Appraisal leads to an increase on organizational performance of universities in Machakos and Kitui as indicated by $\beta 3=0.591$. See table 6 below.

\section{TABLE 6: COEFFICIENTS ${ }^{\mathrm{A}}$}

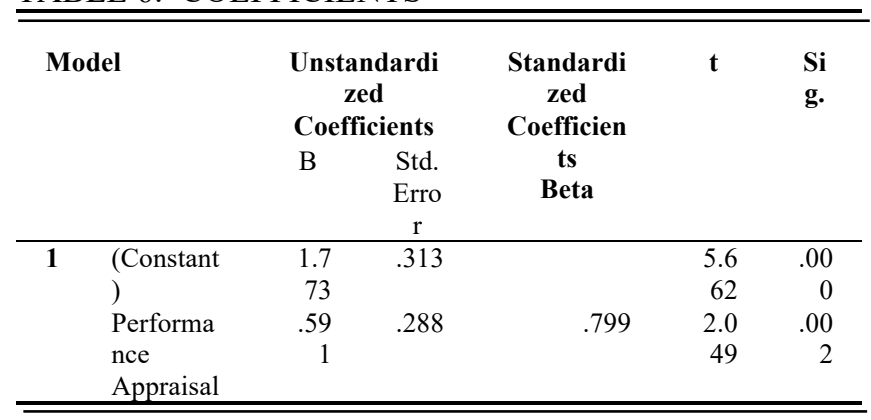

The regression equation for the study was;

$$
\begin{aligned}
& Y=1.773+0.591 X_{1} \\
& \text { Where: }
\end{aligned}
$$

$\mathrm{Y}=\alpha+\beta_{1} \mathrm{X}_{1}$

Where; $\mathrm{Y}=$ Organizational performance

$\alpha=$ constant

$\mathrm{X}_{1}=$ Performance Appraisal

$\varepsilon$ is the error term

\section{CONCLUSIONS AND RECOMMENDATIONS}

\section{A. Conclusion}

The study objective was "to establish the influence of Performance Appraisal on Organization Performance of 
Universities in Machakos and Kitui Counties." The study established that Performance Appraisal has a strong positive influence on Organization Performance (with $\beta_{3}=0.591$, $\mathrm{p}=0.002<0.05$ ). The study also found out that through an employee performance appraisal management evaluates and provides feedback on employee job performance, including steps to improve or redirect activities as needed. Documenting performance provides a basis for pay increases, promotions and rewards.

The study concludes that a performance appraisal evaluates an employee's skills, achievements and growth, or lack thereof. Universities in Machakos and Kitui Counties use performance appraisals to give employees big-picture feedback on their work and to justify pay increases and bonuses, as well as termination decisions. They can be conducted at any given time but tend to be annual, semiannual or quarterly. .

\section{B. Recommendation}

Performance Appraisal is a key function in the improvement of employee performance therefore the university management should establish and practice the best performance appraisal procedures that will build the employee competences as well as achievement of the set organizational objectives.

Management of universities should also ensure that Job descriptions for each staff is clear, specific and well spelt out to mitigate against possible confusion and dissatisfaction of employees in situations where they do not understand what is expected of them and this may result in failure in meeting of their set targets.

Towards fostering smooth performance appraisals, the process of setting objectives and targets should be participatory for ownership during the execution, monitoring and evaluation phases. The targets so set need be within the staff capacity, and well supported by immediate supervisors and university management.

In setting staff targets, supervisors should ensure that this is aligned with the university vision, strategic direction, overall goals and targets of the university and the market information and relevancy.

Finally, this study was carried in universities in Machakos and Kitui Counties with a focus on performance appraisal as a single human resource management practice among many human resource management practices therefore further research is recommended within the same these and other universities or other sectors focusing interrogating other HRM practices and their implications on overall institution performance.

\section{REFERENCES}

[1 ] Armstrong, M. (2007). Human Resource Management Practice, (10th Ed.), London: Kogan Page Limited.

[2] Athey, T.R., \& Orth, M.S. (1999). Emerging Competency Methods for the Future, Human Resource Management, Vol.38:3, 215-224.

[3] Baron, J.M. and Kreps, D.M. (2005) Strategic Human Resources: Frameworks for General Managers. New York: Wiley.

[4] Bouskila-Yam, O., \& Kluger, A. N. (2011). Strength-based performance appraisal and goal setting, Human Resource Management Review, 21(2), 137-147.
[5] Byremo, C (2015). Human Resource Management and Organisational Performance: Does HRM lead to improved organisational performance? Master's Thesis in Organisation, Leadership and Work Department of Sociology and Human Geography Faculty of Social Sciences

[6] Chan, S. \& Kuok, O. (2011). A study of human resources recruitment, selection, and retention issues in the hospitality and tourism industry in Macau. Journal of Human Resources in Hospitality \& Tourism, 10(4), 421-441

[7] Dessler, G. (2008). Human Resource Management (1 $1^{\text {th }}$ ed.). NJ: Pearson Prentice-Hall Upper Saddle River.

[8] Grote, R. C. (2002). Performance appraisal question and answer book: A survival guide for managers. Amacom.

[9] Jensen, M.C., \& Meckling, W.H. (1976). Theory of the firm: Managerial behavior, agency costs and ownership structure. Journal of Financial Economics (October), 3(4):305-360.

[10] Kondrasuk, J. N. (2012). The ideal performance appraisal is a format, not a form. Academy of Strategic Management Journal, 11(1), 115-130.

[11] Kothari, C. (2007). Research Methodology, (2nd Ed).New Delhi.: Longman Oxford Dictionary.

[12]Lagat, C. (2013). A Survey of the Extent of Use of Electronic Recruitment by State Corporations in Kenya, MBA Project in the University of Nairobi.

[13] Locke, E.A and Latham, G.P. (2006). Building a practically useful Theory of goal setting and task motivation: A 35 year Odyssey. American Psychologist, 57,705,717.

[14]Lovke. E.A and Latham, G.O (2006). "New direction in goal setting theory" Current Directions in Psychological Science 15 (5), 265-268

[15] Macey WH, Schneider B, Barbera K.M, Young SA (2009) Employee engagement: tools for analysis, practice, and competitive advantage. Malden WA: Wiley-Blackwell.

[16] Mansor NA (2011) 'Determinants of performance management system in South East Asia', Interdisciplinary Journal of Contemporary Research in Business 3: 43-56.

[17] Mathis, R. L., \& Jackson, J. H. (2011). Human resource management (13th ed.), Mason, OH: Thomson/South-Western.

[18] Muchiri, M. K., (2011). Leadership in Context: A Review and Research Agenda for Sub-Saharan Africa. Journal of Occupational and Organizational Psychology. Vol 84, pp.440 -452.

[19] Mukhwana. E, S. Oure, S. Kiptoo, A. Kande, R. Njue, J. Too and D.K. Some. State of University Education in Kenya. Commission for University Education. Discussion Paper 04. Nairobi, Kenya.

[20] Musyoka, K. (2013). HRM in the SME sector: Valuable employees and coercive networks. The International Journal of Human Resource Management, 16 (11): 1976.

[21] Munjuri M.G, The Effect of Human Resource Management Practices in Enhancing Employee Performance in Catholic Institutions of Higher Learning in Kenya www.sciedu.ca/ijba International Journal of Business Administration Vol. 2, No. 4; November 2011

[22] Mwangi, B.W. (2010), Strategic Human Resource Management Practices adopted by Mobile Phone Serviceproviders in Kenya. Unpublished Project, University of Nairobi.

[23] Nekesa (2013) Succession planning and organization performance in Nzoia sugar company, Kenya

[24] Nginyo E. W. (2010), Employee Performance Management Practices among Insurance Companies in Kenya.Unpublished Project, University of Nairobi.

[25] Nyang'au J. (2014). Higher Education as an Instrument of Economic Growth in Kenya.Kent State University.

[26] Opoku-Mensah, Y (2012). An analysis of Human Resource Planning and its effect on Organizational Effectiveness - A case study of Information Services Department, Accra Office. Unpublished thesis, Kwame Nkrumah University of Science and Technology.

[27] Sabariya, R., and Khita, A.R., (2011) Human Resource Practices and its Effect on Employee Job Satisfaction: A Study on selected small and medium sized iron and steel firm in India public and administration research, Vol. 1 No. 1.

[28] Seiden, S., \& Sowa, J. (2011). Performance management and appraisal in human service organizations: Management and staff perspectives. Public Personnel

[29] Source of Rankings: http://www.webometrics.info : List of top 100 best Universities and Colleges in Kenya in 2019 according to webometrics latest rankings

[30] Stalinski, S., \& Downey, M. (2012). Moving from performance management to managing performance: A systemic approach. People and Strategy, 35(1), 38-41.

[31]Wafula, S. (2014). Linking Business Strategy and Human Resource Management Practices in Multinational Corporations: A Theoretical framework. Advances in International Comparative Management, 8(1), 199-215 